\title{
Prevalence of Herpes Simplex Virus in Pregnant Women from Gangetic Plain Region of Allahabad, India
}

\author{
Omar Ahmed Omar Amar1,2, Harish Kumar Bajaj', Neena Gupta1, Ankit Singla2 ${ }^{2}$, \\ Harison Masih2* \\ ${ }^{1}$ Medical Technology Laboratory, Sam Higginbottom Institute of Agriculture, Technology and Sciences, \\ Allahabad, India \\ ${ }^{2}$ Department of Microbiology and Fermentation Technology, Sam Higginbottom Institute of Agriculture, \\ Technology and Sciences, Allahabad, India \\ Email: ${ }^{*}$ ankitsingla2607@yahoo.co.in, ${ }^{*}$ harisonmasihrns@yahoo.co.in
}

Received 5 May 2015; accepted 4 June 2015; published 8 June 2015

Copyright (C) 2015 by authors and Scientific Research Publishing Inc.

This work is licensed under the Creative Commons Attribution International License (CC BY). http://creativecommons.org/licenses/by/4.0/

(c) (i) Open Access

\section{Abstract}

Herpes Simplex Virus (HSV) is a common pathogen that leads to lifelong latent infection and may be associated with transmission from mother to their fetus. A total of 191 blood samples of pregnant women were collected to check the prevalence of Herpes Simplex Virus (HSV). It was observed that $124(64.9 \%)$ and $04(2.1 \%)$ samples were positive for HSV IgG and HSV IgM, respectively. Seropositivity of HSV IgG was the highest for third trimester and it was followed by second and first trimester; while it was the highest for first trimester for HSV IgM and it was followed by third and second trimester. Seroprevalence of HSV IgG and IgM was statistically insignificant (P > 0.05) according to gestation age. A significant correlation was observed between HSV IgG and age groups of pregnant women; while it was insignificant for HSV IgM. Seroprevalence of $\mathrm{HSV} \mathrm{IgG+}^{+}$IgM- $^{-}$ was $32(53.3 \%), 61(66.3 \%)$, and $27(69.2 \%)$ for first, second and third trimester, respectively. Seroprevalence of $\mathrm{HSV} \mathrm{IgG+}^{+} \mathrm{IgM}^{+}$group was 02 (3.3\%), $01(1.1 \%)$ and $01(2.6 \%)$ for first, second and third trimester, respectively. Seroprevalence of HSV IgG- IgM- group was $26(43.3 \%), 30$ $(32.6 \%)$, and $11(28.2 \%)$ for first, second and third trimester, respectively.

\section{Keywords}

Herpes Simplex Virus, Seroprevalence, IgG, IgM, Quantitative ELISA

\footnotetext{
${ }^{*}$ Corresponding authors.

How to cite this paper: Amar, O.A.O., Bajaj, H.K., Gupta, N., Singla, A. and Masih, H. (2015) Prevalence of Herpes Simplex Virus in Pregnant Women from Gangetic Plain Region of Allahabad, India. Advances in Microbiology, 5, 404-408. 


\section{Introduction}

Viral infections mainly rubella, cytomegalovirus and herpes simplex virus (HSV) account for major part of maternal infections causing unfavourable outcome of pregnancy [1]. HSV infections are among one of the most common infectious diseases in the humans [2]. Primary infection of HSV acquired by women during pregnancy accounts for half of the morbidity and mortality among neonates; while the remaining half result from the reactivation of an old infection [3]. HSV infections are caused by two strains: HSV-1 and HSV-2. Infections with both strains are widespread in all human populations and result in persistent and latent infections. HSV-1 is commonly responsible for orofacial infections and is usually transmitted during childhood and adolescence [4]; HSV-2 is more likely to cause genital lesions [5]. Genital herpes may also be caused by HSV-1 [6]. Genital HSV infection is one of the most common sexually transmitted diseases [7]. After initial infection, the virus can reside as life-long virus and remains latent until the opportunity for recurrence, thus genital herpes is generally a recurrent and incurable viral disease [1]. The majority of both primary and recurrent infections are asymptomatic diseases [8]; however, in symptomatic cases, lesions are very painful [9] and obviously affect the quality of the life in patients [10]. HSV can easily spread in populations because of asymptomatic nature of disease, and is a suitable marker to evaluate the sexual behaviours [9]. It was reported that $70 \%$ of newborn with neonatal herpes infection were infected by their asymptomatic mothers [11].

Primary genital HSV-1 or HSV-2 infection in pregnant women can result in abortion, premature labor, congenital and neonatal herpes [12]. HSV-1 is usually acquired through direct contact with infected lesions or body fluids; typically saliva [13]. Primary HSV-1 infections in children are either asymptomatic or following an incubation period of about one week which can gives rise to mucocutaneous vesicular eruptions [14]. Neonatal infection with HSV is symptomatic in almost all cases and divided into localised, central nervous system (CNS) disease and disseminated disease. Localised congenital HSV infection is limited to the skin, eye or mouth; whereas CNS disease results in encephalitis, and disseminated disease leads to multiple organ damage [15]. It has also been reported that $80 \%$ of infants with disseminated disease die without treatment, and those who survive are often suffering damaged brain [16].

The information on HSV and its seroprevalence in pregnant women is very limited in gangetic plain regions of India. The objectives of the present experiment were to study seroprevalence of HSV (IgG and IgM antibodies) in pregnant women of gangetic plain regions of India and its correlation to gestation age and age groups.

\section{Materials and Methods}

\subsection{Sample Collection and Analysis}

Blood samples from pregnant women were collected by venepuncture in containers under strict aseptic precaution. A total of 191 samples during November 2012 to February 2014 were collected from Arogya Niketan obstetric clinic, Lukerganj in Allahabad, India. Collected samples were centrifuged at $1500 \mathrm{rpm}$ for 10 minutes to separate serum. Serum samples were then kept at $-20^{\circ} \mathrm{C}$ until assayed. Sera samples using Mago4 analyser were screened for the presence of HSV IgM and IgG antibodies by quantitative full automated processing of Enzyme Linked Immunosorbent Assay (ELISA).

\subsection{Interpretation of Results}

A negative result indicated that there was no prior exposure to HSV. A positive result indicated that there was a prior exposure to HSV at some undetermined time. A highly positive result may indicate acute or recent disease.

\subsection{Statistical Analysis}

Data obtained in this study were analyzed using CHI-Square. A statistically significant difference was considered if $\mathrm{P}<0.05$ was obtained.

\section{Results and Discussion}

A total of 124 (64.9\%) and 04 (2.1\%) out of 191 samples were positive for HSV IgG and HSV IgM, respectively. The positivity for HSV IgG indicates past infection of HSV, and our findings are similar with the previous study [17]. The positivity for HSV IgM indicates current or recent infection of HSV as also reported in another study 
[18]. According to gestation age of pregnant women, seropositive of HSV IgG was the highest for third trimester followed by second and first trimester (Table 1). Seropositive of HSV IgM was the highest for first trimester followed by third and second trimester (Table 1). The findings of seropositivity of HSV IgM for first trimester are in accordance to previous study [18]. Seroprevalence of HSV IgG $(P=0.2404)$ and HSV IgM $(P=0.6229)$ in relation to gestation age was statistically insignificant. Some of the previous reports have indicated lower seropositivity rate of HSV IgM [19]-[22]; while some other reports have indicated much higher seropositivity [23]-[25] than our findings.

Seropositivity of HSV IgG was $100 \%$ for the age group 36 - 40 years and it was followed by the age groups 21 - 25, 31 - 35, 26 - 30 and $\leq 20$ years, respectively (Table 2). One of the previous studies has also shown the $100 \%$ seropositivity of HSV IgG in the age group of 36 - 40 years [26]. A significant correlation was observed between HSV IgG and age groups of pregnant women; while it was insignificant for HSV IgM (Table 2). Seropositivity for HSV IgM was only positive in the age group of 21 - 25 years (Table 2).

The seropositivity of $\operatorname{IgG}^{+} / \operatorname{IgM}^{-}$was the highest in third trimester and it was followed by second and first trimester; while seropositivity was the highest in the first trimester for $\operatorname{IgG}^{+} / \operatorname{IgM}^{+}$and $\operatorname{IgG}^{-} / \operatorname{IgM}^{-}$(Table 3). Primary HSV infection during first half of pregnancy is associated with an increased frequency of spontaneous abortion, still birth, and congenital malformation [3] (Table 3).

\section{Conclusion}

A high seroprevalence of Herpes Simplex Virus was detected in the examined samples. It was much higher for IgG compared to IgM. Therefore, it is necessary to diagnose the pregnant women for the possibility of HSV in-

Table 1. Seroprevalence of HSV IgG \& IgM in pregnant women according to gestation age.

\begin{tabular}{|c|c|c|c|c|c|}
\hline \multirow{2}{*}{ Gestational age } & \multirow{2}{*}{$\begin{array}{l}\text { Total number } \\
\text { (\%) }\end{array}$} & \multicolumn{2}{|c|}{ HSV IgG } & \multicolumn{2}{|c|}{ HSV IgM } \\
\hline & & Positive (\%) & Negative (\%) & Positive (\%) & Negative (\%) \\
\hline First trimester & $60(31.4)$ & 34 (56.7) & $26(43.3)$ & $02(3.3)$ & 58 (97.7) \\
\hline Second trimester & $92(48.2)$ & $62(67.4)$ & $30(32.6)$ & $01(1.1)$ & 91 (98.9) \\
\hline \multirow[t]{2}{*}{ Third trimester } & $39(20.4)$ & 28 (71.8) & $11(28.2)$ & $01(2.6)$ & 38 (97.4) \\
\hline & 191 & \multicolumn{2}{|c|}{ P-value $=0.2404$} & \multicolumn{2}{|c|}{ P-value $=0.6229$} \\
\hline
\end{tabular}

Table 2. Seroprevalence of HSV IgG and IgM according to age groups of pregnant women.

\begin{tabular}{|c|c|c|c|c|c|}
\hline \multirow{2}{*}{$\begin{array}{l}\text { Age group } \\
\text { (years) }\end{array}$} & \multirow{2}{*}{ Total number } & \multicolumn{2}{|c|}{ HSV IgG } & \multicolumn{2}{|c|}{ HSV IgM } \\
\hline & & Positive (\%) & Negative (\%) & Positive (\%) & Negative (\%) \\
\hline$\leq 20$ & 18 & $08(44.4)$ & $10(55.6)$ & $00(00)$ & $18(100)$ \\
\hline $21-25$ & 115 & $86(74.8)$ & $29(25.2)$ & $04(3.5)$ & 111 (96.5) \\
\hline $26-30$ & 45 & $26(57.8)$ & $19(42.2)$ & $00(00)$ & $45(100)$ \\
\hline $31-35$ & 11 & $08(72.7)$ & 03 (27.3) & $00(00)$ & $11(100)$ \\
\hline \multirow[t]{2}{*}{$36-40$} & 02 & $02(100)$ & $00(00)$ & $00(00)$ & $02(100)$ \\
\hline & 191 & \multicolumn{2}{|c|}{$\mathrm{P}$-value $=0.0364$} & \multicolumn{2}{|c|}{$\mathrm{P}$-value $=0.6092$} \\
\hline
\end{tabular}

Table 3. Distribution of three groups of HSV IgG/IgM in pregnant women according to gestation age.

\begin{tabular}{ccccc}
\hline Gestation age & Total number (\%) & $\operatorname{IgG}^{+} / \operatorname{IgM}^{-}(\%)$ & $\operatorname{IgG}^{+} / \operatorname{IgM}^{+}(\%)$ & $02(3.3)$ \\
\hline First trimester & $60(31.4)$ & $32(53.3)$ & $01(1.1)$ & $\operatorname{IgG}^{-} / \operatorname{IgM}^{-}(\%)$ \\
Second trimester & $92(48.2)$ & $61(66.3)$ & $01(2.6)$ & $30(32.6)$ \\
Third trimester & $39(20.4)$ & $27(69.2)$ & P value $=0.3966$ \\
\hline
\end{tabular}


fection so that it could be minimized by proper medication. We also believe that health awareness and personal hygiene will be helpful to decrease the risk of HSV infection in pregnant women.

\section{Acknowledgements}

The first author is thankful to Libyan Government, Libya to provide financial support under in-service candidate scholarship for higher education in India.

\section{References}

[1] Johnson, P.M., Barnes, R.M., Hart, C.A. and Francis, W.J. (1984) Determinants of Immunological Responsiveness in Recurrent Spontaneous Abortion. Transplantation, 38, 280-284. http://dx.doi.org/10.1097/00007890-198409000-00016

[2] Brugha, R., Keersmaekers, K., Renton, A. and Meheus, A. (1997) Genital Herpes Infection: A Review. International Journal of Epidemiology, 26, 698-709. http://dx.doi.org/10.1093/ije/26.4.698

[3] Haider, M., Rizvi, M., Khan, N. and Malik, A. (2011) Serological Study of Herpes Virus Infection in Female Patients with Bad Obstetric History. Biology and Medicine, 3, 284-290.

[4] Arduino, P.G. and Porter, S.R. (2008) Herpes Simplex Virus Type 1 Infection: Overview on Relevant Clinico-Pathological Feature. Journal of Oral Pathology and Medicine, 37, 107-121. http://dx.doi.org/10.1111/j.1600-0714.2007.00586.x

[5] Nahmias, A.J., Lee, F.K. and Beckman-Nahmias, S. (1990) Sero-Epidemiological and Sociological Patterns of Herpes Simplex Virus Infection in the World. Scandinavian Journal of Infectious Disease. Supplemental, 69, 19-36.

[6] Pickering, J.M., Whitworth, J.A., Hughes, P., Kasse, M., Morgan, D., Mayanja, B., Van der Paal, L. and Mayaud, P. (2005) Aetiology of Sexually Transmitted Infections and Response to Syndromic Treatment in Southwest Uganda. Sexually Transmitted Infections, 81, 488-493. http://dx.doi.org/10.1136/sti.2004.013276

[7] Howard, M., Sellors, J.W., Jang, D.L., Robinson, N.J., Fearon, M., Kaczorowski, J. and Chernesky, M. (2003) Regional Distribution of Antibodies to Herpes Simplex Virus Type 1 (HSV-1) and HSV-2 in Men and Women in Ontario, Canada. Journal of Clinical Microbiology, 41, 84-89. http://dx.doi.org/10.1128/JCM.41.1.84-89.2003

[8] Wald, A. and Ashley-Morrow, R. (2002) Serologic Testing for Herpes Simplex Virus HSV-1 and HSV-2 Infection. Clinical Infectious Diseases, 35, S173-S182. http://dx.doi.org/10.1086/342104

[9] Corey, L. and Handsfield, H.H. (2000) Genital Herpes and Public Health: Addressing a Global Problem. The Journal of the American Medical Association, 283, 791-794. http://dx.doi.org/10.1001/jama.283.6.791

[10] Mark, H., Gilbert, L. and Nanda, J. (2009) Psychosocial Well-Being and Quality of Life among Women Newly Diagnosed with Genital Herpes. Journal of Obstetric, Gynaecologic and Neonatal Nursing, 38, 320-326. http://dx.doi.org/10.1111/j.1552-6909.2009.01026.x

[11] Rudnick, C.M. and Hoekzema, G.S. (2002) Neonatal Herpes Simplex Virus Infections. American Family Physician, 65, 1138-1142.

[12] Kimberlin, D.W. and Whitley, R.J. (2005) Neonatal Herpes: What Have We Learned? Seminars in Paediatric Infectious Diseases, 16, 7-16. http://dx.doi.org/10.1053/j.spid.2004.09.006

[13] David, R. (2012) Integrative Medicine. Elsevier Health Sciences, Amsterdam.

[14] Gonzalez, M. and Sanjuan, N.A. (2013) Striated Muscle Involvement in Experimental Oral Infection by Herpes Simplex Virus Type 1. Journal of oral pathology and Medicine, 42, 486-490. http://dx.doi.org/10.1111/jop.12051

[15] Remington, J.S., Klein, J.O., Wilson, C.B., Nizet, V. and Maldonado, Y. (2011) Infectious Diseases of the Fetus and Newborn. 7th Edition, Elsevier Saunders, Philadelphia.

[16] Brown, Z. (2004) Preventing Herpes Simplex Virus Transmission to the Neonate. Herpes, 11, 175A-186A.

[17] Mohamed, J., Majeed, H.A. and Ali, I.A. (2011) Performance of Serological Diagnosis of TORCH Agents in Aborted versus Non Aborted Women of West Province in Iraq. Medical Journal of Tikrit, 172, 141-147.

[18] Padmavathy, M., Mangala, G., Malini, J., Umapathy, B.L., Navaneeth, B.V., Mohit, B. and Shruthi, H. (2013) Seroprevalence of TORCH Infections and Adverse Reproductive Outcome in Current Pregnancy with Bad Obstetric History. Journal of Clinical Biomedical Science, 3, 62-71.

[19] Alzahrani, A.J., Obeid, O.E., Almulhim, A.A., Awari, B., Taha, A., Al-Ajmi, F. and Al-Turkistani, H.K. (2005) Analysis of Herpes Simplex 1 and 2 IgG and IgM Antibodies in Pregnant Women and Their Neonates. Saudi Journal of Obstetric Gynaecology, 5, 53-57.

[20] Ozdemir, M., Kalem, F., Feyzioglu, B. and Bysal, B. (2011) Investigation of Viral Pathogen during Pregnancy in a 
City Region in Turkey. Anatolian Journal of Clinical Investigation, 5, 78-81.

[21] Vilibik-Cavlek, T., Ljubin-Sternak, S., Ban, M., Kolaric, B., Sviben, M. and Mlinaric-Galinovic, G. (2011) Seroprevalence of TORCH Infections in Women of Childbearing Age in Croatia. The Journal of Maternity-Fetal \& Neonatal Medicine, 24, 280-283. http://dx.doi.org/10.3109/14767058.2010.485233

[22] Nabi, S.N., Wasey, A., Haider, K.M.T.S., Khan, A.A. and Hoque, M.M. (2012) Seroprevalence of TORCH Antibody in Pregnant Women. Journal of Armed Forces Medical College, 8, 35-39.

[23] Duran, N., Fugen, Y., Cuneyt, E. and Fatih, K. (2004) Asymptomatic Herpes Simplex Virus Type 2 (HSV-2) Infection among Pregnant Women in Turkey. Indian Journal of Medical Research, 120, 106-110.

[24] Abu-Madi, M.A., Behnke, J.M. and Dabritz, H.A. (2010) Toxoplasma gondii Seropositivity and Co-Infection with TORCH Pathogens in High-Risk Patients from Qatar. The American Society of Tropical Medicine and Hygiene, 82, 626-633. http://dx.doi.org/10.4269/ajtmh.2010.09-0530

[25] Al-Marzoqi, A.H.M., Kadhim, R.A., Al-Janabi, D.K.F., Hussein, H.J. and Al Taee, Z.M. (2012) Seroprevalence Study of IgG and IgM Antibodies to Toxoplasma, Rubella, Cytomegalovirus, Chlamydia Trachomatis and Herpes Simplex II in Pregnancy Women in Babylon Province. Biology, Agriculture and Healthcare, 2, 159-164.

[26] Lin, H., He, N., Su, M., Feng, J., Chen, L. and Gao, M. (2011) Herpes Simplex Virus Infections among Rural Residents in Eastern China. BMC Infectious Disease, 11, 69. http://dx.doi.org/10.1186/1471-2334-11-69 